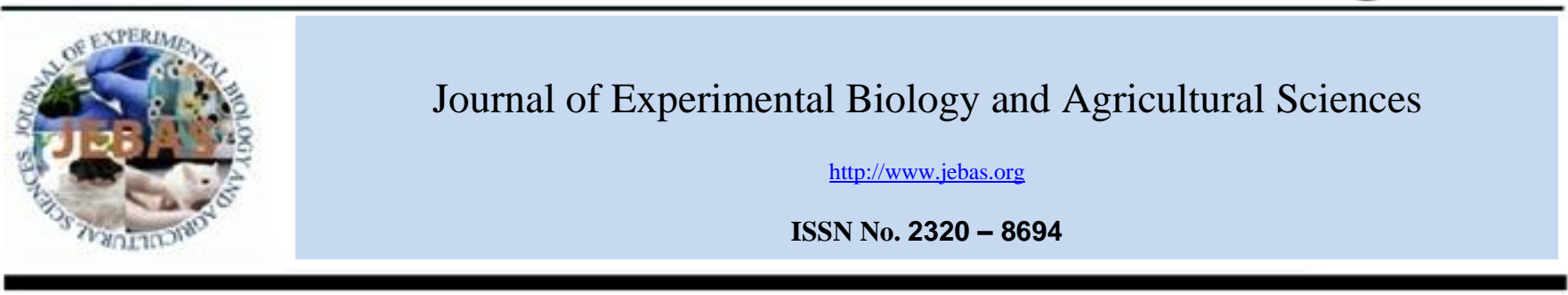

\title{
ASSESSING BEHAVIOUR OF FARMERS IN LINKING TO VILLAGE INSTITUTION: DAIRY SOCIETY'S PERSPECTIVE FROM SEMIARID REGIONS, GUJARAT, INDIA
}

\author{
Hardev Choudhary ${ }^{*}$, Ravikumar RK, and Vipin Kumar
}

National Innovation Foundation-India, Satellite complex, Ahmedabad Gujarat 380015

Received - July 12, 2016; Revision - September 15, 2016; Accepted - October 01, 2016

Available Online - October 13, 2016

DOI: http://dx.doi.org/10.18006/2016.4(Spl-2-SSPN).S9.S16

\begin{abstract}
KEYWORDS
Farmer

Dairy

Institution

Behaviour

Semiarid region

ABSTRACT

Dairy Co-operative Societies (DCS) in India are an important entity in linking smallholder livestock producers with external market. This helps smallholder producer(s) in occupational diversification and gainful income. These economically important institutions also serve social purposes. Co-operative member farmers get an opportunity to interact among themselves as well members outside their society. In semiarid regions, the nature of dependence on these institutions among communities for their livelihood becomes particularly more important. The present study appreciates behaviour of farmers to supply milk to dairy society in Panchmahal district, a semiarid region of Gujarat state, India. The relationship pattern of socioeconomic variables viz., age, education, land size and total milk production were assessed towards linkage of farmers with this particular village institution. The nature of such linkage by society with local institutions often determines technological refinement, intervention and adoption. The study did not find any significant relationship for variables like age, education and total milk production in respect to farmers approaching milk cooperative societies. However, land holding size among respondents appeared to be a significant factor towards supply of milk to societies/society. This clearly demonstrates importance of identifying and understanding variables that can influence livestock interventions through dairy societies. The developmental intermediations must take this into account for welfare of farmers in semiarid region.
\end{abstract}

* Corresponding author

E-mail: hardev@nifindia.org (Hardev Choudhary)

Peer review under responsibility of Journal of Experimental Biology and Agricultural Sciences.

Production and Hosting by Horizon Publisher India [HPI] (http://www.horizonpublisherindia.in/).

All rights reserved.
All the article published by Journal of Experimental Biology and Agricultural Sciences is licensed under a Creative Commons Attribution-NonCommercial 4.0 International License Based on a work at www.jebas.org.

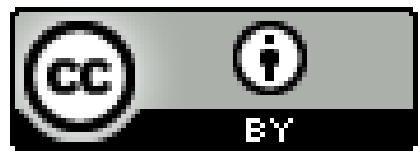




\section{Introduction}

Rainfed agriculture play an important role in Indian economy as nearly 100 million ha of land is under rainfed cultivation (Mynavathi \& Jayanthi, 2015). The nature of agricultural cultivation in these regions was less intensive, serving subsistence requirements of farmers (Ravikumar et al., 2015a). Under such circumstances, dairy farming with support of crop farming does provide steady flow of income and visualized as a viable enterprise (Chaurasiya et al., 2016). The importance of animal husbandry in rainfed regions were reinforced as these areas did not avail greater benefit through technologies responsible for green revolution in India (Kumar \& Singh, 2008). Livestock in theseregions plays pivotal rolein smallholder production system as it meets unexpected household expense (Ibrahim et al., 2014). The economic efficiency in small holder production units were determined by institutional factors, socioeconomic and farm characteristics (Masuku et al., 2014).Further in recent times, agriculture farming experiences change in institutional arrangements as private stakeholders had emerged (Herzfeld \& Jongeneel, 2012). There is a need to relook at institutions in the sphere of farmers interface as demand for milk and milk products has been on rise (Gautam et al., 2010).This is very much evinced in dryland livestock production system as there is pressure on natural resources due to increase in human population (Nyberg et al., 2015).

\subsection{Technology Advancement for livelihood}

Initiatives were taken to minimize technological gap in subsistence farming, a characteristic of most developing countries wherein communities rely on farming for food security and income generation (Larsen \& Lilleor, 2014). Studies hadfound that extent of adoption of farm practices were influenced by variables such as education, operational landholding, extension contact, innovation proneness and decision making ability (Singha \& Baruah, 2012). However, the disconnect between policy development and implementation has been known (Warren et al., 2016). This is pertinent as farmers in rainfed regions were not involved comprehensively while setting up priorities for research (Ravikumar et al., 2015a). Intervention programs were initiated with assumption that farmers can afford and make use of it (Nkya et al., 2007). It was illustrated at field of action that role of societies refining technology is crucial for wider diffusion of innovation. Farmer based assessment methods enable exchange of information and for effective implementation for livestock health system (Ravikumar et al., 2016). Silvestre \& Neto (2014) expressed concern over social exclusion and wealth congregation due to limited use of technologies by economically poor section. The context is challenging with scenario that 60 percent of farming community in Asia have entitlement for only 28 percent of arable land in the world (Uotila \& Dhanapala, 1994). The viability of technology or techno-economic utility has to be seen holistically during implementation and not in fragmented manner (Hiremath et al.,
2006). Linear model of development of technology from research stations were examined and implementation of technologies through non-linear, open source innovation systems were discussed (Ravikumar et al., 2016a).

\subsection{Social setting and characteristics of rainfed agriculture}

The relevance of psychological variables which may influence farmers decision have to be understood (Borges et al., 2014).Studies by Gebrezgabher et al. (2015) refer that age, education and farm size had affected farmers' behaviour in adoption of technology. According to Borges et al. (2016) adoption of an innovation is influenced by attitude, norm and perceived behaviour. Khode et al. (2009) found that attributes like education, land size, daily milk production, daily milk sale had played significant role in implementation of dairy management practices. In their social learning system, farmers were influenced by web of influencers and work within their boundary of practice (Oreszczyn et al. 2010).The decision making ability of end users need to be examined for developing suitable communication strategies (Alarcon et al.,2014). The adoption of technologies for rural community has to be through partnership of all stakeholders (Dubeuf, 2014; Hani \& Mustapit, 2016). It was felt to improvise such lowinput-low output smallholder livestock system with frontline demonstration and sustaining farmers skill through training (Pourouchottamane et al., 2012).

Farmers' adaptive measures need to be comprehensively understood from household, village and community, which are unit of beneficiary (Singh et al., 2014). This only can enhance the scope to plan suitable strategies for improvising their existing social context by strengthening their resilience. Members of community used to reinterpret messages as per their social need and context (Machila et al., 2007). Rufino et al. (2013) found that policies need to provide suitable safety system, market, and infrastructure support to minimize vulnerability in drier regions. Paucity of credit is one of the major characteristic of rainfed agriculture affecting economic activities (Baig et al., 2013). These smallholder system also appear to move towards intensification due to transformationfrom free range dairy system to intensive (stallfed) production system (Hellin et al., 2013). This had created stress on natural resources, changing lifestyle and prevalence of diseases affecting livestock. However, poor availability of quality livestock service has been a constraint (Ravikumar \& Chander, 2011).Adopting low cost locally available technological alternatives may be sustainable in such smallholder system (Ravikumar et al., 2015). Thus accessing financial service and technology through such service improvise household income (Hansen et al., 2015).

\subsection{Social Support Service}

The livelihood factors affecting farmers in rain-fed regions were not well appreciated among stakeholders.Peoples' resilience, their learning strategies and process with which 
local people sustain themselves have to be analysed (Bacud et al., 2014). The interrelationship of stakeholders has been stressed for minimizing impact of drought (Habiba et al., 2012). Such vulnerable regions often affected with drought or drought like situation need to be supported with social service apart from intervention (Keshavarz \& Karami, 2014).Dairy cooperatives in India had provided opportunity in reducing rural poverty through marketing of milk mostly from smallholders (Rajendran \& Mohanty, 2004).

Dairy cooperatives as producer organization had empowered farmer members (Chander \& Sulaiman, 2014). These institutions enable market access and reduce cost of transaction (Latynskiy \& Berger, 2016). It had helped towards participation of women in economic upliftment as reflected in their increased membership percentage to 20 percent (Sheela \& Ramegowda, 2013). Chand et al. (2015) refer that gender equity and increasing herd size up to six can maximize economic sustainability. Though such social institutional system is for poor, wealthier people also join and seek benefit through group action (Fischer \& Qaim, 2012). Thus local institutions can enhance social and economic rewards among participants (Taylor \& Grieken, 2015). Inspite of advantages, these institutions could cater only to 17 percent of marketable commodity of surplus milk (Rathod et al., 2012).

Recognition livestock assets of resource poor, rural women have to be first step as it provides financial security and helps to exercise positive control over their livelihood (Ramkumar et al., 2004). It was opinioned institutional and technological advancement have to be effective for development of dairy sector (Kebebe et al., 2015). These institutions enable farmers to seek information and such interactions indirectly make them toinitiative driven individuals (Hansen, 2015). Ravikumar et al. (2015) indicated that for improvising livelihood strategies in semiarid regions role of dairy cooperative societies need to be focussed.

Drought prone areas require initiatives interms of utilizing niche specific technologies, institutional changes to help stakeholder operating at this interface (Shiferaw et al., 2014). It is in this context a research study was undertaken in semiarid regions of Gujarat to improve the understanding of farmer's behaviour in linking with dairy co-operative society (DCS). This will help scientific communities and extension agencies in executing location specific technologies for enhancing livelihood security in rain-fed regions.

\section{Materials and Method}

The study was conducted to assess role of socioeconomic variables affecting nature of participation by farmers in supply of milk to dairy cooperative society (DCS), a village institution. Two villages viz.,Vankoda of Kothambataluk, Lunawada block and Dhakaliya of Sheherataluk, Shehera block of Panchmahal district in Gujarat state were selected randomly. Twenty seven farmers were randomly selected from each of these two villages during 2012. A total of 54 farmers were selected and constituted sample size for the study. The information from respondents was enumerated with help of structured interview schedule through personnel interview. Their socio-economic status was ascertained with specific reference to age, education, land size and milk yield. The collected data were processed and analysed with help of chisquare test as sample size was more than $50(\mathrm{~N}=54)$. Results obtained were calculated by applying Yates correction where frequency in ordinary table was found less than 10 to avoid inflated chi-square values as per Gupta (2000).

\section{Results and Discussion}

The focus on food security through small holder production system had gained attention and reinforces the need to appreciate factors apart from beliefs and social norms for technological advancement (Martínez-García et al., 2013). Social participation enables society to seek opportunities and avail social security as advocated by social theories which seeks engagement, empowerment and building of capacity (Rainer, 2014). Community action is an important entity for development and it has to be linked with innovation for effective utilization at farmers' field (Seyfang \& Smith, 2007). Involvement of resource poor farmers and evaluating their resources, constraints are essential for implementation of livestock development program (Devesh et al., 2012). Assessing determinants in terms of farmers' behaviour towards marketing channels will provide fillip to knowledge towards improvising better livelihood initiatives (Lubungu et al., 2012). Hence, nature of association between variables likeage, education, size of land, total milk production in relation to supply of milk to DCSwere studied and summarized.

Table $12 \times 2$ chi square table reflecting relationship of age towards linkage with DCS.

\begin{tabular}{|c|c|c|c|c|}
\hline \multirow[t]{2}{*}{ SN } & \multirow[t]{2}{*}{ Treatment group } & \multicolumn{3}{|c|}{ Response to supply of milk in DCS } \\
\hline & & Yes & No & Total \\
\hline 1 & Less than Mean Value $[47.18 \pm 1.91$ years] & 15 & 17 & 32 \\
\hline 2 & More than Mean Value [47.18 \pm 1.91 years] & 13 & 9 & 22 \\
\hline & Total & 28 & 26 & 54 \\
\hline
\end{tabular}

Chi square $\chi^{2}=1.35 \mathrm{NS} v=1(n-1)$ 
Table $22 \times 2$ chi square table reflecting relationship of education towards linkage with DCS.

\begin{tabular}{|llccc|}
\hline SN & Treatment group & \multicolumn{2}{c|}{ Response to supply of milk in DCS } \\
\cline { 3 - 5 } & & Yes & No & Total \\
\hline 1 & Upto secondary school & 14 & 18 & 32 \\
\hline 2 & Higher secondary \& above & 14 & 8 & 22 \\
\hline & Total & 28 & 26 & 54 \\
\hline
\end{tabular}

Chi square $\chi^{2}=2.93 \mathrm{NSv}=1(n-1)$

Table 32 X 2 chi square table reflecting relationship of land size towards linkage with DCS.

\begin{tabular}{|c|c|c|c|c|}
\hline \multirow[t]{2}{*}{ SN } & \multirow[t]{2}{*}{ Treatment group } & \multicolumn{3}{|c|}{ Response to supply of milk in DCS } \\
\hline & & Yes & No & Total \\
\hline 1 & Less than Mean value $[4.35 \pm 0.29$ acre of land] & 11 & 24 & 35 \\
\hline 2 & More than Mean value $[4.35 \pm 0.29$ acre of land] & 17 & 02 & 19 \\
\hline & Total & 28 & 26 & 54 \\
\hline
\end{tabular}

Chi square $\chi^{2}=17.66 * v=1(n-1)$

\subsection{Age}

Nishi et al. (2011) found that majority of respondents in dairy societies were in middle age group (31-50 years). The study also vindicated with similar observations. About 40 percent of respondents were found to be above average years of age $(47.18 \pm 1.91)$. The results were interpreted to understand impact of age in supplying milk to dairy cooperative societies. The calculated value of $\chi^{2}$ is less than table value $\chi^{2}=$ 3.85 at $5 \%$ level of significance (Table 1) and results of study did not provide evidence against null hypothesis. The attribute age of respondents did not associate with supply of milk to dairy society. This was in agreement with Khode et al. (2009).

\subsection{Education}

It was found that about 40 percent of farmers in the study region had education of higher secondary \& more. The calculated value of $\chi^{2}$ is less than table value $\chi^{2}=3.85$ at $5 \%$ level of significance (Table 2). This indicates that education did not have any significant association with supply of milk to dairy society among respondents of the study. The livelihood security among farmers in semi-arid regions is focussed on food security (Baumgartner \& Hogger, 2006). Studies indicated that level of education did not influence milk production among dairy animals (Gangasagare \& Karanjkar, 2009). This may be the reason for less influence of education towards linking farmers with village institutions.

\subsection{Size of land}

Ownership rights of land so as to enable integration into desired social process has been stressed (Ellis,1999). About 44 percent of farmers did not supply milk to cooperative societies who had less than $4.35 \pm 0.29$ acre (Mean \pm Standard error) of land. The calculated value of $\chi^{2}$ was greater than table value at $5 \%$ level of significance (Table 3). The size of land had significant association with respondent's behaviour towards supply of milk to dairy society. The study found that farmers with large size of land were more inclined towards supply of milk to dairy society. Market participation is strongly associated with land and this is in concurrence with Olwande et al. (2015).

These inference were in agreement with findings that dairy societies in semi-arid region had significant association with farmers' with more of land ownership. The study aimed to monitorexisting program of dairy cooperatives as a village institution to understand its role in fulfilment of desired objectives. Sheela \& Ramegowda (2013) indicated overall societies were composed primarily of small, marginal (66\%), landless $(21 \%)$ farmer members. Thus providing technological alternatives to these village units have to be examined as they cater to community with more land and not necessarily landless or marginal farmers.

Table 42 X 2 chi square table reflecting relationship of total milk production towards linkage with DCS.

\begin{tabular}{|llccc|}
\hline SN & Treatment group & \multicolumn{3}{c|}{ Response to supply of milk in DCS } \\
\hline 1 & Less than Mean value $[10.11 \pm 0.48$ litre] & Yes & No & Total \\
\hline 2 & More than Mean value $[10.11 \pm 0.48$ litre] & 19 & 14 & 33 \\
\hline & Total & 09 & 12 & 21 \\
\hline
\end{tabular}

Chi square $\chi^{2}=0.60 \mathrm{NS} v=1(n-1)$ 
3.4 Total milk production

Majority of farmers (61.11 percent) were found with their livestock asset to produce less than $10.11 \pm 0.48$ litres (Mean \pm Standard error) of milk per day. The study evaluated association between total milk production and behaviour of farmers towards supply of milk to society. The calculated value of $\chi^{2}$ is less than table value $\chi^{2}=3.85$ at $5 \%$ level of significance (Table 4). Hence, it was concluded that there was no significant association between total milk production and supply of milk to society by farmers. This is in agreement with Pica-Ciamarra et al. (2011) as livestock offers better nourishment to family. The overall experience in dairy farming (Singh et al., 2012) is an important factor, wherein livestock assets are considered for food security at households. Communities in dryland region try to minimize food intake so as to extend supply over time as a pattern of risk adjustment (Tewari \& Gupta 1997). These understanding helps to mobilise farmers with suitable strategies and enable village institutions for delivery or utilization of suitable technologies (Roling 1988).

\section{Conclusion}

Dairy cooperatives play an important role in rural society to link with market forces and for steady flow of income. Association of farmer behaviour with this village institutions need to be examined before conducting intervention program. Farmers with more land size tend to supply milk to dairy society in comparison to other. In semiarid region, farming community depends on livestock as provider of food security and not necessarily on economic return. The research revealed that factors like age, education and total milk production did not influencelinkage with dairy cooperative society. Inspite of presence of marketing channels, carrying capacity of local environment, household as well as ability to undertake risk due to unfavourable seasonal conditions might act as limiting factor towards supply of milk societies. These features have to be distinguished while addressing location specific intervention through dairy cooperative societies in semi-arid regions. The study also infers necessity to relook institutional support for dairy enterprise in-order to improvise social, economic status of landless or less land owning farmers.

\section{Conflict of interest}

Authors would hereby like to declare that there is no conflict of interests that could possibly arise.

\section{Reference}

Alarcon P, Wieland B, Mateus ALP, Dewberry C (2014) Pig farmers perceptions, attitudes, influences and management of information in the decision-making process for disease control. Preventive Veterinary Medicine $116: 223-242$.

Bacud ST, Cardenas VR, Velasco LI (2014) The Sampaguita Livelihood System in Sta. Cruz, Laguna, Philippines: A Case of a Transformative Resilience Development. Procedia Economics and Finance 18 : 439 - 446. DOI: 10.1016/S22125671(14)00961-7.

Baig MB, Shahid SA, Straquadine GS (2013) Making rainfed agriculture sustainable through environmental friendly technologies in Pakistan: A review, International Soil and Water Conservation Research $1: 3652$

Baumgartner R, Hogger R (2006) Risks and Opportunities for livelihood security in the villages of North Gujarat, Eds. In search of sustainable livelihood systems, Managing Resources and change. Sage Publications, New Delhi, Pp. 77-79.

Borges JAR, Lansink AGJMO, Ribeiro CM, Lutke V (2014) Understanding farmers' intention to adopt improved natural grassland using the theory of planned behaviour. Livestock Science 169: 163-174

Borges JAR, Tauer LW, Lansink AGJMO(2016) Using the theory of planned behavior to identify key beliefs underlying Brazilian cattle farmers' intention to use improved natural grassland: A MIMIC modelling approach. Land Use Policy 55: 193-203

Chand P, Sirohi S, Sirohi SK(2015) Development and application of an integrated sustainability index for smallholder dairy farms in Rajasthan, India. Ecological Indicators 56: $23-30$.

Chander M, Sulaiman VR (2014) Strengthening Extension and Advisory Services through Producer Organisations: A Case of Milk Producer Cooperatives in India, Proceedings and Recommendations of the Consultations on the role of Producer Organisations in Strengthening Extension and Advisory Provision in the Dairy/Livestock Sector in India, (AugustOctober, 2014).

Chaurasiya KK, Badodiya SK, Somvanshi SPS, Gaur CL (2016) Entrepreneurial behaviour of dairy farmers in Gwalior district of Madhya Pradesh. Indian Journal of Dairy Science 69 : 112-115.

Devesh T, Sharma AK, Katoch S, Chander M, Mane BG, Sharma P (2012) High altitude livestock farming: A participatory appraisal in Himachal Pradesh, India. Indian Journal of Animal Sciences 82 : 644-648.

Dubeuf JP (2014) Science, technology, innovation and governance for the goat sectors, Small Ruminant Research $121: 2-6$

Ellis F (1999) Rural livelihood diversity in developing countries: Evidence and policy implications, Series No.40, Natural Resource perspectives, Overseas Development Institute, London, UK. 
Fischer E, Qaim M (2012) Linking Smallholders to Markets: Determinants and Impacts of Farmer Collective Action in Kenya. World Development 40 : 1255-1268.

Gangasagare PT, Karanjkar LM (2009) Status of milk Production and economic profile of dairy farmers in the Marathwada region of Maharashtra. Veterinary World 2 : 317320.

Gautam, Dalal RS, Pathak V (2010) Indian dairy sector: Time to revisit operation flood. Livestock Science 127 : 164-175.

Gebrezgabher SA, Meuwissen MPM, Kruseman G, Lakner D, Lansink AGJMO (2015) Factors influencing adoption of manure separation technology in the Netherlands. Journal of Environmental Management 150: 1-8. DOI: http://dx.doi.org/10.1016/j.jenvman.2014.10.029.

Gupta SP (2000) Statistical methods, Sultan Chand and Sons, New Delhi, India.

Habiba U, Shaw R, Takeuchi Y (2012) Farmer's perception and adaptation practices to cope with drought: Perspectives from North western Bangladesh. International Journal of Disaster Risk Reduction 1: 72-84.

Hani ES, Mustapit (2016) Stakeholder Response to the Development Strategy of Sugarcane Dry Land Agriculture in East Java. Agriculture and Agricultural Science Procedia 9: 469-474.

Hansen BG (2015) Financial extension that challenges farmers' thinking in discussion clubs helps farmers improve their problem solving abilities. Agricultural Systems 132: 85-92.

Hansen K, Kim JJ, Suffian S, Mehta K(2015) Leveraging informal lending mechanisms to facilitate technology transfer and microenterprise in developing countries. Technology in Society 41: 65-75.

Hellin J, Erenstein O, Beuchelt T, Camacho C, Flores D (2013) Maize stover use and sustainable crop production in mixedcrop-livestock systems in Mexico. Field Crops Research 153: 12-21. http://dx.doi.org/10.1016/j.fcr.2013.05.014.

Herzfeld T, Jongeneel R (2012) Why do farmers behave as they do? Understanding compliance with rural, agricultural, and food attribute standards. Land Use Policy 29 : 250-260.

Hiremath BN, Raju KV, Patel A (2006) Technology adoption and farm management in rural livelihood systems in Gujarat. In: Baumgartner R, Hogger R (Eds.) In search of sustainable livelihood systems, Managing Resources and change, Sage Publications, New Delhi, pp. 94-125.

Ibrahim MAR, Dorina M, Abdelrazek I (2014) How Rural Agricultural Development Projects (Animal Production) can
Use Projects Benefits for Improving the Economics States of Farmers. Procedia Economics and Finance 8: 484-489.

Kebebe E, Duncan AJ, Klerkx L, de Boer IJM, Oosting SJ (2015) Understanding socio-economic and policy constraints to dairy development in Ethiopia: A coupled functionalstructural innovation systems analysis. Agricultural Systems 141:69-78

Keshavarz M, Karami E (2014) Farmers' decision-making process under drought. Journal of Arid Environments 108: 4356.

Khode NV, Sawarkar SW, Banthia VV, Nande MP, Basunathe VK (2009) Adoption of improved dairy cattle management practices under Vidarbha Development programme package. Indian Research Journal of Extension Education 9 : 80-84.

Kumar A, Singh DK (2008) Livestock Production Systems in India: An appraisal across agro-ecological regions. Indian Journal of Agricultural Economics 63 : 577-597.

Larsen AF, Lilleor HB (2014) Beyond the field: The impact of farmer field schools on food security and poverty alleviation. World Development 64: 843-859. DOI: http://dx.doi.org/10.1016/j.worlddev.2014.07.003.

Latynskiy E, Berger T (2016) Networks of Rural Producer Organizations in Uganda: What Can be Done to Make Them Work Better?. World Development 78: 572-586.

Lubungu M, Chapoto A, Tembo G (2012) Smallholder farmers participation in livestock markets: The case of Zambian farmers, working paper No. 66, Indaba Agricultural Policy Research Institute (IAPRI), Lusaka, Zambia. Available at http://fsg.afre.msu.edu/zambia/WP66.pdf access on 06/06/2016

Machila N, Emongor R, Shaw AP, Welburn SC, McDermott J, Maudlin I, Eisler MC (2007) A community education intervention to improve bovine trypanosomiasis knowledge and appropriate use of trypanocidal drugs on smallholder farms in Kenya. Agricultural Systems 94 : 261-272. doi:10.1016/j.agsy.2006.09.004.

Martínez-García CG, Dorward P, Rehman T (2013) Factors influencing adoption of improved grassland management by small-scale dairy farmers in central Mexico and the implications for future research on smallholder adoption in developing countries. Livestock Science 152 : 228-238

Masuku BB, Masuku MB, Belete A (2014) Economic efficiency of smallholder dairy farmers in Swaziland: An application of the profit function. Journal of Agricultural Studies, 2 :132-146.

Mynavathi VS, Jayanthi C (2015) Dry land integrated farming system - A review. Agricultural Reviews 36 : 67-72. 
Nishi, Sah AK, Kumar R (2011) Dairy farmers' satisfaction with dairy cooperative societies: A case study. Indian Research Journal of Extension Education 11: 74-78.

Nkya R, Kessy BM, Lyimo ZC, Msangi BSJ, Turuka F, Mtenga K (2007) Constraints on smallholder market oriented dairy systems in the north eastern coastal region of Tanzania. Tropical Animal Health and Production 39 : 627-636. DOI:10.1007/s11250-007-9059-4

Nyberg G, Knutsson P, Ostwald M, Öborn I, Wredle E, Otieno DJ, Mureithi S, Mwangi P, Said MY, Jirström M, Grönvall A, Wernersson J, Svanlund S, Saxer L, Geutjes L, Karmebäck V, Wairore JN, Wambui R, Leeuw JD, Malmer A (2015) Enclosures in West Pokot, Kenya: Transforming land, livestock and livelihoods in drylands, Pastoralism. Research, Policy and Practice 5:25. DOI: 10.1186/s13570-015-0044-7.

Olwande J, Smale M, Mathenge MK, Place F, Mithöfer D (2015) Agricultural marketing by smallholders in Kenya: A comparison of maize, kale and dairy. Food Policy 52: 22-32.

Oreszczyn S, Lane A, Carr S (2010) The role of networks of practice and webs of influencers on farmers' engagement with and learning about agricultural innovations. Journal of Rural Studies $26: 404-417$

Pica-Ciamarra U, Baker D, Chassama J, Fadiga M, Nsiima L (2011) Linking smallholders to livestock markets in Tanzania:Combing Market and Household Survey Data, Joint paper of the World Bank, FAO, AU-IBAR, ILRI with support from the Gates Foundation. Available at http://documents.worldbank.org/curated/en/928401468133181 076/pdf/866410WP0PAP0a00Box385182B00PUBLIC0.pdf access on $03 / 06 / 2016$.

Pourouchottamane R, Venkatasubramanian V, Singha AK, Mishra A, Pankaj PK (2012) Training needs analysis of livestock farmers and rural youth of North Eastern India. Veterinary Practitioner $13: 374-379$.

Rainer S (2014) Social participation and social engagement of elderly people. Procedia-social and Behavioural Sciences 116:780-785. DOI: 10.1016/j.sbspro.2014.01.297.

Rajendram K, Mohanty S (2004) Dairy cooperatives and milk marketing in India: Constraints and Opportunities. Journal of Food distribution research 35: 34-41.

Ramkumar S, Rao SVN, Waldie K (2004) Dairy cattle rearing by landless rural women in Pondicherry: A path to empowerment. Indian Journal of Gender Studies 11: 206-222.

Rathod P, Nikam TR, Landge S, Hatey A (2012) Perceived Constraints in Livestock Service Delivery by Dairy Cooperatives: A Case Study of Western Maharashtra, India. Indian Journal of Dairy Science 65 : 423-430. DOI: http://dx.doi.org/10.5146/ijds.v65i5.25437.g11829.
Ravikumar RK, Chander M (2011) Livestock extension education activities of the State Departments of Animal Husbandry (SDAH) in India: A case of Tamil Nadu state. Indian Journal of Animal Sciences 81: 757-762.

Ravikumar RK, Choudhary H, Kumar V (2015) Means for retaining farming communities in semi-arid regions of Gujarat State. Agricultural Update 10 : 158-163. DOI: 10.15740/HAS/AU/10.2/158-163.

Ravikumar RK, Kumar V, Choudhary H, Kinhekar AS, KumarV (2015a) Efficacy of indigenous polyherbal ectoparasiticide formulation against hard tick infestation in cattle (Bosindicus). Ruminant Science 4: 43-47.

Ravikumar RK, Kumar V, Khuman LY, Kinhekar AS, Thakur D, Kumar V (2016a) Integrating indigenous knowledge research system (IKRS) and/with livestock health intervention program to complement natural resource conservation. Advances in Animal and Veterinary Sciences $4: 32-42$. DOI: http://dx.doi.org/10.14737/journal.aavs/2016/4.1s.32.42.

Ravikumar RK, Periyaveeturaman C, selvaraju D, Kinhekar AS, Dutta L, Kumar V (2016) Community oriented ectoparasite intervention system: concepts for on-farm application of indigenous veterinary medication. Advances in Animal and Veterinary Sciences 4 : 9-19.

Roling N (1988) Extension Science: Information systems in agricultural development, Cambridge University Press, Cambridge. pp. 1-18.

Rufino MC, Thornton PK, Ng'ang'a SK, Mutie I, Jones PG, van Wijk MT, Herrero M (2013) Transitions in agro-pastoralist systems of East Africa: Impacts on food security and poverty. Agriculture, Ecosystems and Environment, 179:215- 230. http://dx.doi.org/10.1016/j.agee.2013.08.019.

Seyfang G, Smith A (2007) Grassroots Innovations for sustainable development: Towards a new research and policy agenda. Environmental Politics 16 : 584-603.

Sheela KS, Ramegowda A (2013) Dairy cooperatives and empowerment of women. International Journal of Advanced Social Science and Humanities $2: 34-42$.

Shiferawa B, Tesfayeb K, Kassiec M, Abatec T, Prasannac BM, Menkird A (2014) Managing vulnerability to drought and enhancing livelihood resilience in sub-Saharan Africa: Technological, institutional and policy options. Weather and Climate Extremes 3:67-79. http://dx.doi.org/10.1016/j.wace.2014.04.004.

Silvestre BS, Neto RS (2014) Capability accumulation, innovation, and technology diffusion: Lessons from a Base of the Pyramid cluster. Technovation 34 : 270-283. 
Singh KM, Meena MS, Bharati RC, Kumar A (2012) An Economic Analysis of Milk Production in Bihar. Indian Journal of Animal Sciences 82: 1233-1237.

Singh NP, Bantilan C, Byjesh K (2014) Vulnerability and policy relevance to drought in the semi-arid tropics of Asia - A retrospective analysis. Weather and Climate Extremes 3:5461. http://dx.doi.org/10.1016/j.wace.2014.02.002.

Singha AK, Baruah MJ(2012) Adoption behaviour of dairy innovations by small farmers under different farming systems in Assam. Indian Research Journal of Extension Education 12: 60-64.

Taylor BM, Grieken MV (2015) Local institutions and farmer participation in agri-environmental schemes. Journal of Rural Studies 37: 10-19
Tewari DD, Gupta AK (1997) How Bankers and Small Households Adjust to Risk in Dryland Agriculture: A Case Study of Two Blocks in Karnataka, India. The Journal of Entrepreneurship $\quad 6$ : $35-51$. 10.1177/097135579700600103.

Uotila, Dhanapala (1994) Dairy development through cooperative structure, FAO Regional Office for Asia and the Pacific, Maliwan, Mansion, PhraAtit Road, Bangkok 10200, Thailand, In Experiences in Dairy Development. World Animal Review, Available at http://www.fao.org/docrep/T3080T/t3080T0a.htm access on 25.3.2006.

Warren CR, Burton R, Buchanan O, Birnie RV (2016) Limited adoption of short rotation coppice: The role of farmers' sociocultural identity in influencing practice. Journal of Rural Studies 45: 175-183. 